\title{
Identification of antibiotic producing bacteria from soil samples of Dhaka, Bangladesh
}

\begin{abstract}
Multidrug-resistance in bacteria is a serious and common problem that demands an urgent need to discover new antibiotics. In recent years multiple approaches have been taken to develop novel, potent, and less toxic antibiotics from natural sources against pathogenic bacteria. Soil has been considered as a natural source of obtaining bacteria with the ability to produce noble antibiotics. We studied soil samples in Dhaka municipal area to identify bacteria having antibiotic producing ability. We have isolated three bacterial strains (named $\mathrm{K} 1, \mathrm{~K} 2$, and K19) producing growth inhibitory components effective against both gram positive and gram negative bacteria. Bacteria were found to produce circular, regular, white colonies. Gram staining indicated that K1, K2 was gram negative, while K19 was gram positive. Cellular morphology was studied by scanned electron microscopy (SEM) and found that K1, K2, and K19 are short rod shaped. It was found that the antibacterial factors from the bacterium are released in to the cell culture medium. The antibacterial activity of the component(s) remains active when the cell culture supernatant was heated at $450 \mathrm{C}$ for five minutes. Further characterization of the bacteria and their antibacterial compounds are in progress in our laboratory.
\end{abstract}

Volume 4 Issue 6 - 2017

\author{
Kohinur Begum,' Sultana Juhara Mannan,' \\ Md Mahinur Rahman,' Alani Antoine \\ Mitchell, ${ }^{2}$ Ruth Opoku, ${ }^{2}$ Nadia Burgos, ${ }^{2}$ Jaleel \\ Shepherd, ${ }^{2}$ ljaz Ahmed, ${ }^{2}$ Alam Nur-E-Kamal ${ }^{2}$ \\ 'Department of Pharmacy,ASA University Bangladesh, \\ Bangladesh \\ ${ }^{2}$ Department of Biology, Medgar Evers College of the City \\ University of New York, USA
}

\begin{abstract}
Correspondence: Alam Nur E Kamal, Department of Biology, Medgar Evers College of the City University of New York, 1638 Bedford Avenue, Brooklyn, New York I I 225, USA , Tel 7I8-2705078,Email alam@mec.cuny.edu
\end{abstract}

Received: April 26, 2017| Published: May 16, 2017

Keywords: Soil; Bacteria; Isolation; Antibacterial compounds

Abbreviations: TSA, trypticase soy agar; TSB, trypticase soy broth; E. coli, escherichia coli; S. aureus, staphylococcus aureus

\section{Introduction}

Microbial population in soil depends of various factors such as temperature, salt concentration, $\mathrm{pH}$, carbon sources etc. While growing in soil, microorganisms compete with each other for growth advantages and evolve a mechanism to win over other organisms. ${ }^{1}$ One of those mechanisms includes production of components that inhibit the growth of other microorganisms. Diversity in environment in the biosphere favor amplification of specific types of microorganism. The microbial pool therefore evolves a wide range of biochemical mechanisms which can be manipulated and utilized for the benefit of other organisms including human. Identification of such microorganisms raises a possibility of finding noble antibiotics with a potential clinical use. ${ }^{2,3}$

Bacterial pathogens (e.g. Mycobacterium tuberculosis, Staphylococcus aureus etc.) have been reported to frequently acquire resistance to antibiotics, and exhibit multi-drug resistance. In recent years multidrug-resistance in bacteria has raised a serious concern among scientific community. It highlights a greater need to find more antibiotics as well as alternative antimicrobial substances that can be used for use in clinics, food preservation and dairy products. ${ }^{4,5}$ Consequently, research on antimicrobial compounds as a new class of drugs has increased in the recent past as they exhibit both narrow and broad spectrum inhibitory activities against grampositive and gram-negative bacteria. An attractive alternative method to discover antibacterial agents is the use of promoter-inducible reporter assays. ${ }^{6-8}$ The selective induction of the reporter fusion indicates that a compound is perturbing the pathway of interest. ${ }^{8}$ Antibiotic resistance is a great challenge to modern medicine and demands discovery of novel antibiotics. ${ }^{9-11}$ Microorganisms were found to produce secondary metabolites with a diverse chemical structure and antimicrobial activities. ${ }^{12,13}$ These findings raise a high possibility to identify bacterial strains from soil samples that might produce reagents with biochemical and pharmacological importance.

The ability of Actinomycetes to produce a variety of bioactive substances has been known for long time and being utilized in research and synthesize bioactive compound in numerous academic and industrial laboratories. These studies have tremendous impact on application against many human infections. ${ }^{14-16}$ Antibiotics resistance against infectious diseases has increased in recent years. ${ }^{17}$ Antibiotic resistance of pathogens (e.g. Staphylococcus aureus) causes a dangerous threat to the treatment of human infections. Scientists and medical professionals are worried about the potential threat. They are pursuing new experiments to discover unique and novel antibiotics against drug resistant pathogens. ${ }^{18,19}$ We have attempted to identify antibiotic producing bacteria from soil samples in fish and vegetable dump areas from Dhaka, Bangladesh. We have studied the biochemical and morphological properties of these bacteria. In this study, we report identification of three bacterial isolates producing antibacterial compound(s). Characterization of antibacterial factor(s) may lead to the discovery of novel antibiotic(s) with clinical application.

\section{Materials and methods}

\section{Chemicals and reagents}

Trypticase soy broth (Hi-Media, India), Trypticase soy agar (HiMedia, India), crystal violet, Gram's iodine, safranin, ethyl alcohol, commercial antibiotic disc (Hi-Media, India).

\section{Sample collection}

Soil samples were collected from fish, vegetables and fruits dump area from Dhaka City.

\section{Bacterial culture}

About five grams of soil sample were suspended in TSB medium. The microbial suspension was further diluted (10-4) with the same 
medium. About100 $\mu$ l of microbial suspension was spread on TSA plate and incubated for 24 hours. The bacterial colonies were isolated and grown in TSB. Bacteria were characterized.

\section{Gram staining}

A smear of bacterial cells was prepared on a clean glass slide and the smear was then allowed to air-dry followed by a mild heat fixation. Crystal violet solution was added onto bacterial smear and incubated for one minute. The smear was washed with water. Mordant Gram's iodine solution was then added onto bacterial smear and incubated for one minute. The smear was decolorized by washing with $95 \%$ ethyl alcohol and rinsed with water. Finally safranin was used as counterstain for one minute and washed with water. Cells were then air dried and studied under microscope.

\section{Antibacterial activity of soil isolates of bacteria}

Bacterial strains isolated from soil samples were studied to determine their ability to kill other bacteria. The test was performed against E. coli, and $S$. aureus. E. coli or $S$. aureus were spread on separate TSA plates. The soil bacterial isolates were then inoculated as small spot with appropriate marking. The plates were then incubated at $37 \mathrm{oC}$ for 24 hours. Bacteria which can kill or produce chemicals that inhibit bacterial (E. coli, S. aureus, S. paratyphi, Acenobacter, $V$. cholerae and $S$. dysentery) growth will exhibit clear transparent zones around the inoculated spots of inoculation. After 24 hours of incubation, zone diameter was measured and recorded.

\section{Results and discussion}

\section{Identification of bacteria in soil samples from Dhaka city area}

Soil around fish and vegetable waste dump area is an excellent environment for microbial growth due to abundant supply of organic material. In addition, warm temperature in Bangladesh favors bacterial growth. Hence we have selected and studied bacterial population in different food waste dumping area of Dhaka city. Soil samples were collected from fish and vegetable waste dumping area of Dhaka city. Soil samples were suspended in PBS and diluted to 10-4. A portion of diluted liquid was spread on to TSA plates. Bacteria were allowed to grow in a $37^{\circ} \mathrm{C}$ as shown in a sketch of procedure (Figure 1). After 24 hours of incubation, growth of bacteria was studied. Bacterial colonies were identified based on their color and morphology (data not shown). Single colonies were picked up and cultured in TSB for further analysis. Bacteria observed in this study were of different types as observed by morphology, color, and edge of colonies. The result obtained in this study is consistent with the previous reports. ${ }^{20,21}$

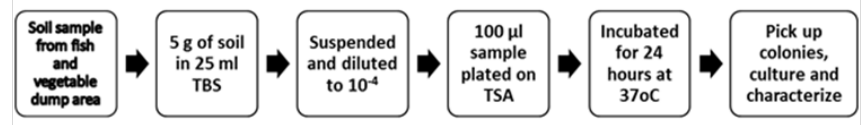

Figure I A flow chart showing the summary of isolation of bacteria from soil samples. Bacterial colonies were picked up as shown in the figure above. Individual colonies were cultured and used for characterization.

In recent years new bacterial pathogens are being found to be emerging with resistance to almost all antibiotics. It has become essential to develop novel antibiotics to overcome forth coming challenge of treating infectious diseases. ${ }^{22,23}$ We were interested if any of the soil bacterial isolates has the ability to produce chemicals that inhibit other bacterial growth. We inoculated a small dot of soil bacterial isolates on top of TSA plate pre-inoculated with E. coli, or $S$. aureus. Upon incubation for 24 hours, it was found that some of our bacterial isolates inhibit growth of both gram positive and gram negative bacteria (Figure 2A,2B). Interestingly $\mathrm{K} 1$, and $\mathrm{K} 2$ exhibited strong inhibitory effect on the growth of some pathogenic organisms (S. paratyphi and Acenobacter) (Table 1). Similarly K19 showed strong growth inhibitory activity against pathogenic bacteria, $V$. cholerae and S. dysentery (Table 1).

Table I Antibacterial activity of soil bacterial isolates. Each of the bacterial isolates (KI, K2, and KI9) was studied for their ability to produce bactericidal chemicals. Individual test organism (listed in the Table) was inoculated on TSA plate by spreading with cotton swabs. A small amount of bacterial isolate was then spot inoculated on indicated position. TSA plates were then incubated for 24 hours and studied for the ability of soil bacterial isolates to inhibit growth of test organisms. Clear zone was measured and recorded. Experiment was repeated three times showing similar results

\begin{tabular}{llllllll}
\hline \multirow{2}{*}{ Bacterium } & \multicolumn{2}{l}{ Zone of Inhibition $\mathbf{( M m )}$} & & & \\
\cline { 2 - 7 } & S. aureus & B. subtilis & E. coli & S. Paratyphi & Acenobacter & V. cholerae & S. dysentery \\
\hline KI & 20 & 18 & $>20$ & $>30$ & $>30$ & 0 & 0 \\
K2 & 10 & 6 & $>20$ & $>30$ & $>30$ & 0 & 0 \\
K19 & 30 & ND & 20 & $>10$ & 0 & 20 & 20 \\
\hline
\end{tabular}
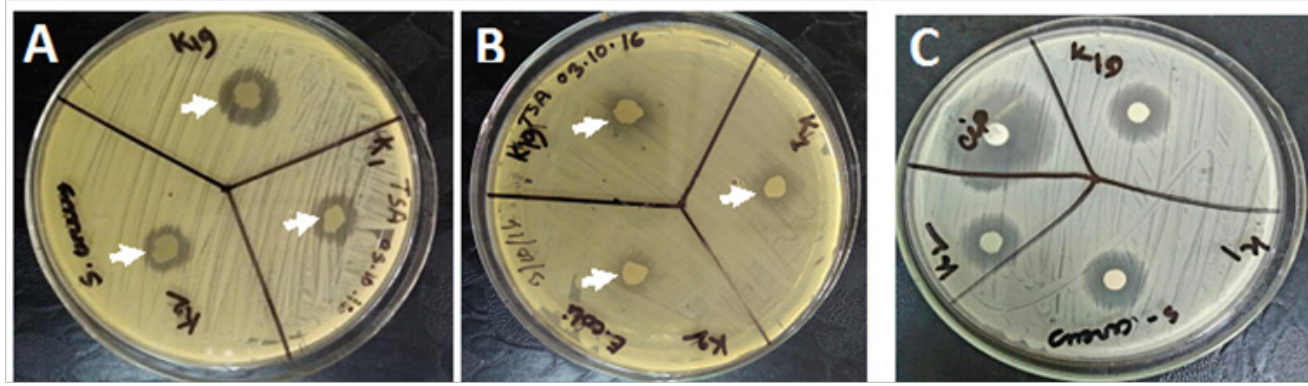

Figure 2 Bactericidal activity of soil bacterial isolates. Each of the bacterial isolates (KI, K2, and KI9) were studied for their ability to produce bactericidal chemicals. S. aureus (A) or E. coli(B)cultures were inoculated on TSA plate by spreading with cotton swabs. A small amount of bacterial isolate was then spot inoculated on indicated position.TSA plates were then incubated for 24 hours and studied for the ability of soil bacterial isolates to inhibit growth of $\mathrm{S}$. aureus(A) and E. coli (B). Clear zone (shown by arrow) was measured. C. Inhibitory effect of culture supernatant. Bacterial isolates (KI, K2, and KI9) from soil samples were cultured in TSB for 24 hours.TSB culture was centrifuged at $12 \mathrm{krpm}$ for $30 \mathrm{~min}$. The supernatant was collected and filtered through $0.22 \mu \mathrm{m}$ filter.About $50 \mu \mathrm{l}$ of filtrate was soaked onto $3 \mathrm{MM}$ paper discs. Discs were applied onto pre-inoculated S. aureus TSA plate. The plate was incubated at $37 \circ \mathrm{C}$ overnight and studied for antibacterial activity. Arrows show clear zone where S. aureus did not grow. Ciprofloxacin (5 $\mu \mathrm{g}$ per disc) used as a positive control. 
We studied whether antibacterial compound(s) diffuses out of the cell of soil bacterial isolates. Bacterial cultured medium was studied by disc diffusion method. Culture supernatant from K1, K2, and K19 inhibited growth of S. aureus (Figure 2C). Ciprofloxacin (5 $\mu \mathrm{g}$ per disc) was used as a positive control. Number of antibacterial compounds produced by these bacteria and the quantity of these compounds in the bacterial culture supernatant remain unknown. Therefore, a direct comparison between effect of ciprofloxacin and antibacterial compounds was impossible. We have heated the culture supernatant for 5 minutes and found no loss of its antibacterial activity (data not shown). Further studies are in progress to isolate and characterize antibacterial compounds produced by $\mathrm{K} 1, \mathrm{~K} 2$, and K19. Once purified, the effect of antibacterial compounds produced by $\mathrm{K} 1, \mathrm{~K} 2$, and $\mathrm{K} 19$ will be compared with commercially available antibiotics.

Table 2 Effect of temperature on growth of bacterial isolates. One loopful of fresh bacterial cultures were inoculated into respective $5 \mathrm{ml}$ TSB in test tube and incubated at $4{ }^{\circ} \mathrm{C}, 20^{\circ} \mathrm{C}, 37^{\circ} \mathrm{C}, 45^{\circ} \mathrm{C}, 60^{\circ} \mathrm{C}$ and $70^{\circ} \mathrm{C}$ for $24 \mathrm{~h}$. Turbidity of the culture media was determined after $24 \mathrm{~h}$ and indicated by + (Growth) and - (no growth) sign

\begin{tabular}{lllllll} 
Bacteria & $4^{\circ} \mathrm{C}$ & $20^{\circ} \mathrm{C}$ & $37^{\circ} \mathrm{C}$ & $45^{\circ} \mathrm{C}$ & $6^{\circ} \mathrm{C}$ & $7^{\circ} \mathrm{C}$ \\
\hline $\mathrm{KI}$ & - & + & + & + & - & - \\
$\mathrm{K} 2$ & - & + & + & + & - & - \\
$\mathrm{K} 19$ & - & + & + & + & - & - \\
\hline
\end{tabular}

\section{Bacterial isolates from soil samples of Dhaka city area are short rod-shaped cell}

Soil bacterial isolates were studied by gram staining. It was found that $\mathrm{K} 1$ and $\mathrm{K} 2$ were gram negative, while $\mathrm{K} 19$ was gram positive (Figure 3A). Cellular morphology of all three (K1, K2, and K19) soil bacterial isolates was studied by scan electron microscopy. As shown in Figure 3B all three bacterial isolates were of small rod-shaped (coccobacilli).
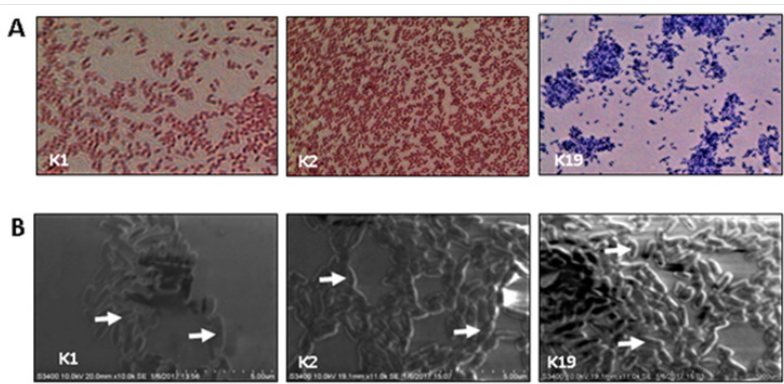

Figure 3A Gram staining of bacterial isolates. Each bacterial sample (KI, $\mathrm{K} 2$, or $\mathrm{K} 19$ ) were spreaded on a glass slide and gram staining was performed as described in "Methods and Material". Bacterial sample was studied under microscope and pictures were captured.

B. Bacterial isolates (KI, K2, or $\mathrm{K} 19$ ) were spreaded on a small cover slip. Morphology of bacteria was studied under a scan electron microscope and images were captured. Arrow shows position of individual cell.

\section{Tolerance of bacterial isolates to environmental factors}

All three bacterial isolates were studied for their tolerance to temperature, salt and $\mathrm{pH}$. It was found that $\mathrm{K} 1, \mathrm{~K} 2$, and $\mathrm{K} 19$ could grow between $20 \mathrm{oC}$ and $45 \mathrm{oC}$ (Table 2). All three bacteria could grow at $\mathrm{pH}$ range of 6-11 as well as $\mathrm{NaCl}$ concentration of $1-12 \%$ (data not shown). It remained to study further the enzyme producing ability of these bacterial isolates. In addition molecular analysis such as rRNA sequence analysis needs to be completed to determine the identity of each of these bacterial isolates. ${ }^{25}$

\section{Conclusion}

This study describes isolation of three soil bacteria from Dhaka city area. Bacterial isolates were found to produce antibacterial components against both gram positive and negative cells. Bacterial cell morphology was studied by scan electron microscopy and found to be short rod shaped. Antibacterial compound(s) was found to diffuse out of the cell. Further studies are in progress to determine chemical nature of the antimicrobial compound(s).

\section{Acknowledgements}

The authors are thankful to the Department of Pharmacy, ASA University, Bangladesh for providing the necessary facilities to carry out the research work of this study. The work also was supported by the NIH-RISE (5R25GM105553-04).

\section{Conflicts of interest}

There is no conflict of interest.

\section{Funding}

None.

\section{References}

1. Hibbing M, Fuqua C, Parsek M, et al. Bacterial competition: surviving and thriving in the microbial jungle. Nat Rev Microbiol. 2010;8(1):1525 .

2. Bizuye A, Moges F, Andualem B. Isolation and screening of antibiotic producing actinomycetes from soils in Gondar town, North West Ethiopia. Asian Pac J Trop Dis. 2013;3(5):375-381.

3. Berdy J. Bioactive microbial metabolites. J Antibiot. 2005;58(1):1-26.

4. Gerits E, Blommaert E, Lippell A, et al. Elucidation of the mode of action of a new antibacterial compound active against Staphylococcus aureus and Pseudomonas aeruginosa. PLoS One. 2016;11(5):e0155139.

5. Donadio S, Carrano L, Brandi L, et al. Targets and assays for discovering novel antibacterial agents. J Biotechnol. 2002;99(3):175-185.

6. Shapiro E, Baneyx F. Stress based identification and classification of antibacterial agents: second-generation Escherichia coli reporter strains and optimization of detection. Antimicrob Agents Chemother. 2002;46(8):2490-2497.

7. Goh EB, Yim G, Tsui W, et al. Transcriptional modulation of bacterial gene expression by subinhibitory concentrations of antibiotics. Proc Natl Acad Sci USA. 2002;9(26):17025-17030.

8. Fischer HP, Brunner NA, Wieland B, et al. Identification of antibiotic stress-inducible promoters: a systematic approach to novel pathwayspecific reporter assays for antibacterial drug discovery. Genome Res. 2004;14(1):90-98.

9. Hoopwood DA. Antibiotics: Opportunities for genetic manipulation, JSTOR Philosophical Transaction of the royal society of London. Series B Biological. 1989;324(1224):1-3.

10. Ball AP, Bartlett JG, Craig WA, et al. Future trends in antimicrobial chemotherapy: expert opinion on the 43rd ICAAC. $J$ Chemother. 2004;16(5):419-436.

11. Hancock REW. The end of an era? Nat Rev Drug Discov. 2007;6:28.

12. Stachelhaus T, Schneider A, Marahiel MA. Rational design of peptide antibiotics by targeted replacement of bacterial and fungal domains. Sci. 1995;269(5220):69-72. 
13. Drablos F, Nicholson DG, Ronning ME. Study of zinc coordination in bacitracin A. Biochim. Biophys Acta. 1999;1431:433-442.

14. Retinowati W. Identification of Streptomyces sp-MWS1 producing antibacterial compounds. Indonesian J Trop Infect Dis. 2010;1(2):8285 .

15. Khanna M, Solanki R, Lal R. Selective isolation of rare actinomycetes producing novel antimicrobial compounds. Int J Adv Biotech Res. 2011;2(3):357-375.

16. Nonoh JO, Lwande W, Masiga D, et al. Isolation and characterization of Streptomyces species with antifungal activity from selected national parks in Kenya. Afr J Microbiol Res. 2010;4(9):856-864.

17. Ilic SB, Kontantinovic SS, Todorovic ZB. UV/Vis analysis and antimicrobial activity of Streptomyces isolates. Med Biol. 2005;12(1):44-46.

18. Adwan G, Mhanna M. Synergistic effects of plant extracts and antibiotics on Staphylococcus aureus strains isolated from clinical specimens. Middle-East J Sci Res. 2008;3(3):134-139.

19. Aghamirian RM, Ghiasian AS. Isolation and characterization of medically important aerobic actinomycetes in soil of Iran. Open Microbiol J. 2009;3:53-57.
20. Barlaz MA, Schaefer DM, Ham RK. Bacterial population development and chemical characteristics of refuse decomposition in a simulated sanitary landfill. Appl Environ Microbiol. 1989;55 (1):55-65.

21. Song L, Wang Y, Zhao H, et al. Composition of bacterial and archaeal communities during landfill refuse decomposition processes. Microbiol Res. 2015;181:105-111.

22. Kealey C, Creaven CA, Murphy CD, et al. New approaches to antibiotic discovery. Biotechnol Lett. 2017;10:1-13.

23. Marston HD, Dixon DM, Knisely JM, et al. Antimicrobial Resistance. JAMA. 2017;316(11):1193-1204.

24. Alexander M. Introduction to soil microbiology. (2nd edn), John Wiley and Sons Inc, New York, USA. 1977: 472.

25. Yarza P, Yilmaz P, Pruesse E, et al. Uniting the classification of cultured and uncultured bacteria and archaea using 16S rRNA gene sequences. Nat Rev Microbiol. 2014;2(9):635-645. 